\title{
Is It Possible to Control the Nutrient Regime of Soils with Different Texture through Biochar Substrates?
}

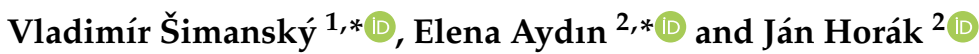 \\ 1 Department of Soil Science, Institute of Agronomic Sciences, Faculty of Agrobiology and Food Resources, \\ Slovak University of Agriculture, 94976 Nitra, Slovakia \\ 2 Institute of Landscape Engineering, Faculty of Horticulture and Landscape Engineering, \\ Slovak University of Agriculture, 94976 Nitra, Slovakia; jan.horak@uniag.sk \\ * Correspondence: vladimir.simansky@uniag.sk (V.Š.); elena.aydin@uniag.sk (E.A.)
}

Citation: Šimanský, V.; Aydın, E.; Horák, J. Is It Possible to Control the Nutrient Regime of Soils with Different Texture through Biochar Substrates?Agronomy 2022, 12, 51 . https://doi.org/10.3390/ agronomy12010051

Academic Editors: Evan A.N. Marks and Xavier Domene

Received: 4 October 2021

Accepted: 24 December 2021

Published: 27 December 2021

Publisher's Note: MDPI stays neutral with regard to jurisdictional claims in published maps and institutional affiliations.

Copyright: (C) 2021 by the authors. Licensee MDPI, Basel, Switzerland. This article is an open access article distributed under the terms and conditions of the Creative Commons Attribution (CC BY) license (https:// creativecommons.org/licenses/by/ $4.0 /)$.
Abstract: Understanding nutrient management is essential to ensure healthy and adequate food production, especially in the context of biochar applied to soil with different soil textures. Additionally, farmers are beginning to understand the importance of nutrient management and there are still several knowledge gaps in this area. Several studies on biochar showed its positive effects, especially in sandy and nutrient-poor soils. There is still a lack of information on the impact of biochar on nutrient regimes in texturally different soils with sufficient nutrient supply and favorable soil chemistry. This study investigates the effect of two biochar substrates (a) biochar blended with farmyard manure (BS1), and (b) biochar blended with farmyard manure and digestate (BS2) applied at rates of 10 and $20 \mathrm{t} \mathrm{ha}^{-1}$ alone or in combination with fertilization on the changes in sorption capacity and nutrient regime of two texturally different soils: (a) sandy Arenosol, and (b) loamy Chernozem, (both in western Slovakia) which have a favorable nutrient content. The results showed that in sandy soil, the BS2 at rate of $20 \mathrm{t} \mathrm{ha}^{-1}$ increased the sum of basic cations (by $+112 \%$ ) and CEC (by $+93 \%$ ) compared to the control. In sandy soil, the content of total P increased by +35 and $+16 \%$ in BS1 $20 \mathrm{tha}^{-1}$ and BS2 $20 \mathrm{t} \mathrm{ha}^{-1}$, respectively, when compared to the unfertilized control. The content of total P increased by $+18 \%$ in BS1 $20 \mathrm{tha}^{-1}$ after fertilization compared to the fertilized control. In loamy soil, the content of total $\mathrm{P}$ increased significantly by +53 and $+14 \%$ in unfertilized treatment BS2 $20 \mathrm{tha}^{-1}$ and fertilized treatment with BS1 at $20 \mathrm{t} \mathrm{ha}^{-1}$ compared to the respective controls. Available Ca increased in sandy soil by +50 and $+53 \%$ in fertilized treatments with BS2 at $20 \mathrm{t} \mathrm{ha}^{-1}$ and BS1 at $20 \mathrm{tha}^{-1}$, respectively, when compared to fertilized control. In loamy soil, available $\mathrm{Mg}$ increased by $+13 \%$ in fertilized treatment with BS1 applied at $20 \mathrm{tha}^{-1}$. In conclusion, BS application at a dose of $20 \mathrm{tha}^{-1}$ had a stronger positive effect on soil sorption parameters in sandy soil than the application dose of $10 \mathrm{t} \mathrm{ha}^{-1}$. The same BS application rate significantly increased total $\mathrm{P}$ in both soils.

Keywords: soil sorption; soil reaction; fertilizer amendment; available nutrients; effeco

\section{Introduction}

Monitoring of the chemical soil parameters is an integral part of modern agricultural practice. It acts as a tool to evaluate the potential of soil to provide ecosystem services such as regulation of nutrients and uptake and food, fuel, and energy production. A frequent assessment of the soil properties is an important indicator for soil management. Based on the content of individual nutrients, the farmers can determine how to implement rational fertilization, which has positive economic and environmental impacts on their farming system. The content of nutrients in the soil is determined by local conditions (parent material, soil texture, weathering processes, climate, etc.), but they can be significantly controlled by planned intervention, particularly fertilization. Since 2000, OECD countries have on average experienced declining trends in nutrient surpluses. Although almost all OECD countries recorded a decrease in phosphorus surpluses, the picture is mixed in 
the case of nitrogen due to increased nitrogen fertilizer application rates. From 1992 to 2014, the average nitrogen surplus fell from $85 \mathrm{~kg} \mathrm{ha}^{-1}$ to $67 \mathrm{~kg} \mathrm{ha}^{-1}$ and the phosphorus surplus from $13 \mathrm{~kg} \mathrm{ha}^{-1}$ to $6 \mathrm{~kg} \mathrm{ha}^{-1}$ In OECD countries. Up to 1990, the average NPK annual doses to arable soil were $220-230 \mathrm{~kg} \mathrm{ha}^{-1}$ in Slovakia. Since that period, the doses of NPK fertilizers dropped significantly to $40-60 \mathrm{~kg} \mathrm{ha}^{-1}$ (especially due to economic reasons). Currently, the nutrient doses are at the level of $100 \mathrm{~kg} \mathrm{ha}^{-1}$ NPK-nitrogen is generally the most applied fertilizer $\left(76.31 \mathrm{~kg} \mathrm{ha}^{-1}\right)$, followed by significantly less amount of phosphorus $\left(14.45 \mathrm{~kg} \mathrm{ha}^{-1}\right)$ and potassium $\left(11 \mathrm{~kg} \mathrm{ha}^{-1}\right)$. The content of soil nutrients has been regularly monitored since 1956, partially because of the introduction of the soil agrochemical testing (SAT), and a Partial Monitoring System of Soil as a part of the Environmental Monitoring of Slovakia [1]. The results of SAT in Slovakia (from 1956 up to the present day) show that the content of available phosphorus in Slovak soils gradually increased due to intensive phosphorus fertilization until the 1990s. However, the phosphorus fertilization was insufficient and at a lower level than the uptake of phosphorus from the soil by crops. Therefore, the content of available phosphorus is currently at a level comparable to the 1970 's. In many cases, the phosphorus in the soil becomes a limiting factor for crop yield and soil quality. This negative trend is also supported by increasing acidity of the soil leading to chemical sorption of phosphorus, and thus a reduction in the availability of phosphorus to plants [2]. In the agricultural soils of Slovakia, the content of available potassium is ranging relatively widely, on average from $121-401 \mathrm{mg} \mathrm{kg}^{-1}$, which represents a "low" up to "very high" supply of potassium (K) to the soils. Since 1993, the K content has decreased on average by 20-25\% [1]. On the other hand, the content of total $\mathrm{Ca}$ is within the range of $0.15-6.0 \%$. Annually, approximately $30 \mathrm{~kg}$ of Ca ha ${ }^{-1}$ is received through the application of manures and composts. Most Ca (approximately $157 \mathrm{~kg} \mathrm{ha}^{-1}$ ) is added through liming of acidic soils [3], but losses through leaching and uptake by crops can represent $50-600 \mathrm{~kg} \mathrm{~kg}^{-1}$ and $125-400 \mathrm{~kg} \mathrm{~kg}^{-1}$, respectively [4,5]. The content of total $\mathrm{Mg}$ ranges from $0.4 \%$ to $0.6 \%$. Available Mg content of $95 \%$ of Slovak soils is between "satisfactory" up to "very high" content. Despite this fact, Kováčik [6] stated that Mg losses can be in the range from $50-80 \mathrm{~kg} \mathrm{ha}^{-1}$.

In the case of some macro-nutrients, there is a continuous significant reduction in their content in the soils of the Slovak Republic. It is the responsibility of farmers to supplement the missing nutrients to the soil through the addition of fertilizers. Generally, the application of mineral fertilizers is the fastest way to increase the nutrient content in the soil for crops in terms of time and efficiency, and their application has increased significantly in recent decades [7]. But fertilization as an agronomic tool of modern agriculture also has some disadvantages-especially its incorrect utilization. The effect of mineral fertilization improves when it is combined with an organic amendment. In such cases, the negative aspects of its application (a reduction of physical properties, acidification, salinization, etc.) can be eliminated. Recently, a pyrolyzed organic soil amendment-biochar and its various combinations with other fertilizers have been used in many regions of the world to sustainably increase the nutrient reserves in the soil. Biochar is a solid material obtained from the thermochemical conversion of biomass in an oxygen-limited environment. Several authors $[5,8]$ reported that applied biochar improved soil quality by increasing soil $\mathrm{pH}$ as a result of a soil acidity reduction-known as the liming effect [9]. This leads to the improvement of cation exchangeability and nutrient preservation within the soil. The application of biochar improves soil fertility through two mechanisms: (1.) adding the nutrients to the soil and/or (2.) retaining the nutrients from other sources, including nutrients from the soil itself. As some authors e.g., [10] have mentioned, biochar serves as an important source of plant nutrients, especially nitrogen in biochar produced from manures and wastes at low temperatures $\left(\leq 400{ }^{\circ} \mathrm{C}\right)$. However, the phosphorus, potassium, and other nutrient contents are generally higher in manure/waste biochars than in biochars made of wood or crop residues. Biochar increases the availability of $\mathrm{N}, \mathrm{Ca}, \mathrm{Mg}, \mathrm{K}, \mathrm{P}$ to the plants, because biochar adsorbs and slowly releases fertilizers [11]. In the case of crops with high nutrient requirements, the application of biochar alone is not always a 
sufficient source to cover nutrient requirements for crop growth and soil productivity. But the application of biochar in combination with other fertilizers or the production of the innovative biochar substrates (BS) can be an effective way to meet the increasing nutrient requirements in intensive agriculture [12]. However, it is important for farmers to know whether a product such as BS brings them benefits through increased yields, improved soil properties, and net economic profit [13]. As biochar is expected to be the unbalanced fertilizer due to its high stability in the soil environment, its addition to the soil may play a key role in nutrient dynamics by directly adding or indirectly affecting the soil properties that increase nutrient availability $[10,11,14]$. Therefore, biochar producers must strive in the process of their production to achieve a product with the most optimal properties or recommend its application with other fertilizers in various combinations $[15,16]$.

The application of biochar and its effect on the soil properties both in Slovakia and globally is not fully understood and requires further research. Published literature presents several examples $[17,18]$ that biochar improves soil fertility, including nutrient regime and soil $\mathrm{pH}$ in coarse and acidic soils rather than in fine soils and soils rich in nutrients with alkaline $\mathrm{pH}$. However, with farmer intervention, even coarse-textured soils can have higher $\mathrm{pH}$ and a good supply of nutrients. In many cases, the content of nutrients in biochar is highly unbalanced as its properties depend on the feedstock, the conditions of biochar production, etc. [19]. This effect can be eliminated by combining biochar with other soil amendments/fertilizers, especially by providing additional nutrients. Many questions arise here. How will be soils that have an alkaline reaction and a good supply of nutrients, but a different soil texture affected by the application of biochar substrates (BS)? How will texturally different soils react to different doses of BS and their combinations with other fertilizers? In our study, we hypothesized that overall, more positive changes will be observed in the treatments with an addition of fertilizers to BS and that a more pronounced effect will be observed at higher application rates of BS. It was assumed that nutrients contained in applied BS will improve the sorption capacity of sandy soil more than of loamy soil $[20,21]$ and that after the addition of BS, the availability of nutrients to plants will decrease. The aims of this study were (1.) to quantify the total and available nutrient contents in texturally different soils after the application of the biochar substrates alone or in combination with additional fertilization, (2.) to determine whether there are direct relationships between $\mathrm{pH}$, sorption and macro-nutrients in the BS amended treatments in the texturally different soils.

\section{Materials and Methods}

\subsection{Experimental Sites and Research Design}

The study was conducted in two research sites at Dolná Streda $\left(48^{\circ} 15^{\prime} 16.6^{\prime \prime} \mathrm{N} 17^{\circ} 43^{\prime} 02.7^{\prime \prime}\right.$ E) and Vel'ké Úl'any $\left(48^{\circ} 09^{\prime} 11.5^{\prime \prime} \mathrm{N} 17^{\circ} 34^{\prime} 57.6^{\prime \prime} \mathrm{E}\right)$, both located in western Slovakia. The climate is temperate with an average annual temperature ranging from $9-10{ }^{\circ} \mathrm{C}$ and the average annual rainfall ranges from $520-600 \mathrm{~mm}$ in both regions. The soils at Dolná Streda and Vel'ké Úl'any are classified as the sandy Haplic Arenosol (Arenic, Calcic) and the loamy Vermic Chernozem (Mollic, Loamic), respectively [22]. The physical and chemical soil characteristics determined before the experiment are listed in Table 1.

Biochar substrates (BS) used in the experiment were provided by Zdroje Zeme a. s. (Slovakia). According to the manufacturer, biochar was made from pyrolyzed hardwood and blended with other organic amendments. Biochar substrate 1 (BS1) was mixed with dried sheep manure in the ratio 1:1 and biochar substrate 2 (BS2) was mixed with dried sheep manure and the residue (digestate) from the biogas plant (cattle manure as feedstock) in the ratio 1:1:1. The selected characteristics of BS sold under trademark "effeco" are summarized in Table 2. 
Table 1. The basic chemical and physical properties of soil before the establishment of the experiments.

\begin{tabular}{|c|c|c|}
\hline Soil Property & $\begin{array}{c}\text { Dolná Streda } \\
\text { Sandy Haplic Arenosol } \\
\text { (Arenic, Calcic) }\end{array}$ & $\begin{array}{l}\text { Vel'ké Úl'any } \\
\text { Loamy Vermic Chernozem } \\
\text { (Mollic, Loamic) }\end{array}$ \\
\hline Sand (\%) & 81.9 & 38.5 \\
\hline Silt $(\%)$ & 10.5 & 47.8 \\
\hline Clay (\%) & 7.60 & 13.7 \\
\hline $\mathrm{OC}\left(\mathrm{g} \mathrm{kg}^{-1}\right)$ & 9.70 & 15.6 \\
\hline Total N (mg kg $\left.{ }^{-1}\right)$ & 1300 & 1000 \\
\hline Available $\mathrm{P}\left(\mathrm{mg} \mathrm{kg}^{-1}\right)$ & 175 & 129 \\
\hline Available $\mathrm{K}\left(\mathrm{mg} \mathrm{kg}^{-1}\right)$ & 165 & 255 \\
\hline $\mathrm{pH}$ & 7.60 & 7.78 \\
\hline
\end{tabular}

Table 2. The basic chemical and physical properties of the used biochar substrates BS1 and BS2.

\begin{tabular}{ccc}
\hline & BS1 & BS2 \\
\hline Pellets (dimensions in mm) & $2 \cdot 2 \cdot 1$ & $2 \cdot 2 \cdot 1$ \\
OC $(\%)$ & 43 & 45.4 \\
Total N $(\%)$ & 1.20 & 1.30 \\
Total P $(\%)$ & 0.49 & 0.79 \\
Total K $(\%)$ & 24.6 & 15.5 \\
pH & 8.18 & 8.44 \\
Total Ca $\left(\mathrm{mg} \mathrm{kg}^{-1}\right)$ & 42,000 & 22,000 \\
Total Mg $\left(\mathrm{mg} \mathrm{kg}^{-1}\right)$ & 4500 & 5800 \\
\hline
\end{tabular}

OC-organic carbon in the biochar substrates.

Detailed information on the experimental design can be found in the work of Šrank and Šimanský [23]. Briefly, the experiment in Dolná Streda was established using the long segment method in autumn 2017 on 10 plots (one treatment $=90 \mathrm{~m}^{2}$ ). The research plots were planted with sunflower (Heliantus annuus L.), durum wheat (Triticum durum Desf.), and maize (Zea mays L.) in 2018, 2019, and 2020, respectively. Eight biochar amended treatments (BS1 $10 \mathrm{tha}^{-1}$, BS1 $20 \mathrm{tha}^{-1}, \mathrm{BS} 210 \mathrm{tha}^{-1}$, BS2 $20 \mathrm{tha} \mathrm{ha}^{-1}, \mathrm{BS} 110 \mathrm{tha}^{-1}+\mathrm{F}$, BS1 $20 \mathrm{tha}^{-1}+\mathrm{F}$, BS2 $10 \mathrm{t} \mathrm{ha}^{-1}+\mathrm{F}$, and BS2 $20 \mathrm{tha}^{-1}+\mathrm{F}$ ) and two control treatments (Co: control-no fertilization and no biochar, Co-F: fertilized control with no biochar) were investigated in 3 replicates. Biochar substrates BS1 and BS2 were applied in autumn 2017 and incorporated into the soil by disk harrow. During the whole period of the experiment, the site was under minimum tillage management. Only disc harrow operations were performed up to a depth of 15-18 cm. Before sowing sunflower in spring 2018, urea was applied to the soil at a dose of $100 \mathrm{~kg} \mathrm{ha}^{-1}$. In autumn 2018 and spring 2019, urea and monoammonium phosphate (AMOFOS NP 12-52) were applied at the rates of $100 \mathrm{~kg} \mathrm{ha}^{-1}$ and $100 \mathrm{~kg} \mathrm{ha}^{-1}$, respectively. The same fertilizers and the same application doses were used with maize in 2020.

The experiment in Vel'ké Úl'any was established using a random plot arrangement method with double repetition in spring 2018 with a total of 10 treatments (one treatment $=25 \mathrm{~m}^{2}$ ). The preceding crop was carrot (Daucus sativus Hoffm.). Green pepper (Capsicum annuum L.), beetroot (Beta vulgaris L.) and green pepper were planted in 2018, 2019, and 2020, respectively. Similarly to the experiment in Dolná Streda, the experiment consisted of the same eight treatments: Co: control without fertilization, BS1 $10 \mathrm{tha}^{-1}, \mathrm{BS} 120 \mathrm{tha}{ }^{-1}$, BS2 $10 \mathrm{tha}^{-1}$, BS2 $20 \mathrm{tha}^{-1}, \mathrm{Co}-\mathrm{F}$ as fertilized control, BS1 $10 \mathrm{tha}^{-1}+\mathrm{F}, \mathrm{BS} 120 \mathrm{tha}^{-1}+\mathrm{F}, \mathrm{BS} 2$ $10 \mathrm{tha}^{-1}+\mathrm{F}$ and BS2 $20 \mathrm{tha}^{-1}+\mathrm{F}$. Biochar substrates BS1 and BS2 were incorporated into the soil at a depth of 10-12 cm together with granulated manure Italpollina at the rate of $0.85 \mathrm{t} \mathrm{ha}^{-1}$ before planting green pepper in 2018. Italpollina was applied once again at a rate of $1 \mathrm{t} \mathrm{ha}^{-1}$ before planting the beetroot in spring 2019. In spring 2020, NPK fertilizer at the rate of $200 \mathrm{~kg} \mathrm{ha}^{-1}$ was applied and incorporated into the soil before planting green pepper. Conventional tillage practices were applied at the site during the experiment. The 
soil was always tilled in autumn to a depth of $20 \mathrm{~cm}$. In spring, the soil was consequently prepared by a tiller. Depending on the type of grown vegetable, mechanical hoeing was also used in combination with the chemical weed control.

\subsection{Soil Analyzes}

The soil samples were taken from all treatments of both experiments twice a year (in spring and autumn) during the period from 2018-2020 from a depth of 0-20 cm. Samples were measured for: soil $\mathrm{pH}$-potentiometrically; sorption parameters such as: hydrolytic acidity (Ha) - titration in the extract of $1 \mathrm{~mol} \mathrm{dm}^{-3} \mathrm{CH}_{3} \mathrm{COONa}$, sum of basic cations (SBC) - titration in leachate of $1 \mathrm{~mol} \mathrm{dm}^{-3} \mathrm{HCl}$-Kappen method [24]. In the final samples, the values of cation exchange capacity (CEC) were calculated according to Equation (1).

$$
\mathrm{CEC}=\mathrm{Ha}+\mathrm{SBC},
$$

Base saturation (Bs) of the soil colloidal sorption complex was calculated according to Equation (2).

$$
\mathrm{Bs}=\mathrm{SBC} / \mathrm{CEC} \cdot 100 \text {, }
$$

Total contents of $\mathrm{K}, \mathrm{Ca}$, and $\mathrm{Mg}$ were determined by flame atomic absorption spectrometry (Perkin Elmer AA 2100) and the content of total P by the molybdenum-blue method after samples were incorporated into a mixture of $\mathrm{HF}, \mathrm{HClO}_{4}$, and $\mathrm{HNO}_{3}$ in a ratio of 3:1:1 by volume. Available forms of the investigated elements were measured by flame atomic absorption spectrometry (Perkin Elmer AA 2100) and the content of available $\mathrm{P}$ was estimated by the molybdenum-blue method after sample extraction in Mehlich III solution [25].

\subsection{Statistical Analyzes}

The statistical analyzes were performed using the Statgraphics Centurion XV.I programme (Statpoint Technologies, Inc., Washington, DC, USA). One-way analysis of variance (ANOVA) and the least significant difference (LSD) method were used to compare treatment means for the two types and levels of biochar substrates application and their combination with other fertilization at $p \leq 0.05$. To study the relationships between the soil $\mathrm{pH}$, sorption parameters, and available forms of $\mathrm{P}, \mathrm{K}, \mathrm{Ca}$, and $\mathrm{Mg}$, a single linear regression analysis was applied.

\section{Results and Discussion}

The findings in this study confirmed that the application of different types of biochar substrates (BS) to different soils affected the evaluated soil properties. The soil $\mathrm{pH}$ and soil sorption parameters of unfertilized soils and at treatments with BS after 3 years of experiments are listed in Table 3. In sandy soil, the overall average $\mathrm{pH}$ values ranged from 7.41 to 7.63 , i.e., from neutral to slightly alkaline. In the case of BS2 treatments (BS2 $10 \mathrm{t} \mathrm{ha}^{-1}$ and BS2 $20 \mathrm{t} \mathrm{ha}^{-1}$ ), the soil $\mathrm{pH}$ values significantly increased (both by $+3 \%$ ) after the application of BS to the soil compared to the unfertilized control Co. However, the combination of BS together with additional fertilization had no effect on average $\mathrm{pH}$ in sandy soil compared to the fertilized control for the period 2018-2020. In loamy soil, the $\mathrm{pH}$ was within the range of 7.83-8.03, and the application of BS did not alter the observed average soil $\mathrm{pH}$. Our results are consistent with the published results of several studies [21,26-29]. El-Naggar, et al. [21] stated that a more pronounced effect of biochar on soil $\mathrm{pH}$ changes was usually observed in sandy soils and in soils with acidic $\mathrm{pH}$ than in soils with finer texture. Overall, the soil $\mathrm{pH}$ values in our study were lower in sandy soil. A general slightly higher increase in sandy soil $\mathrm{pH}$ compared to loamy soil may be a result of the initial $\mathrm{pH}$ of both soils. In addition, both soils contained carbonates, and both tested BS contained basic cations and had an alkaline $\mathrm{pH}$. In general, by increasing soil $\mathrm{pH}$, biochar positively affected an increase of cation exchange capacity of the soil (CEC). An increase in soil $\mathrm{pH}$ increases the electrostatic bonds between the soil particles and exchange 
cations, as well as increases the overall sorption capacity [30]. In our study, the effect of BS on soil $\mathrm{pH}$ was different depending mainly on the soil type/class, but also on the type of BS and its application rate or combination with additional fertilization. A stronger effect was observed in sandy soil, which corresponds to the observed average values of sorption parameters in both trials (Table 3 ).

Table 3. Parameters of the soil sorption complex (mean \pm standard deviation for 2018-2020).

\begin{tabular}{|c|c|c|c|c|c|}
\hline \multirow{2}{*}{ Treatments } & \multirow{2}{*}{$\mathrm{pH}$} & $\mathrm{Ha}$ & SBC & CEC & Bs \\
\hline & & $\mathrm{mmol} \mathrm{kg}^{-1}$ & $\mathrm{mmol} \mathrm{kg}^{-1}$ & $\mathrm{mmol} \mathrm{kg}^{-1}$ & $\%$ \\
\hline \multicolumn{6}{|c|}{ Sandy soil } \\
\hline Co & $7.41 \pm 0.19^{a}$ & $3.29 \pm 0.49^{a}$ & $19.7 \pm 5.85^{a}$ & $23.0 \pm 6.10^{a}$ & $81.3 \pm 1.30^{a}$ \\
\hline BS1 $10 \mathrm{t} \mathrm{ha}^{-1}$ & $7.57 \pm 0.16^{a b}$ & $3.19 \pm 1.22^{\mathrm{a}}$ & $24.8 \pm 7.20^{a b}$ & $28.0 \pm 7.30 \mathrm{ab}$ & $88.3 \pm 5.13^{a b}$ \\
\hline BS1 $20 \mathrm{tha}^{-1}$ & $7.53 \pm 0.14^{\mathrm{ab}}$ & $2.94 \pm 0.78^{a}$ & $34.1 \pm 8.12^{\mathrm{ab}}$ & $37.0 \pm 8.13^{\mathrm{ab}}$ & $91.7 \pm 1.27^{b}$ \\
\hline BS2 $10 \mathrm{t} \mathrm{ha}^{-1}$ & $7.63 \pm 0.20^{b}$ & $2.57 \pm 0.41^{a}$ & $28.7 \pm 8.10^{\mathrm{ab}}$ & $31.3 \pm 9.11^{\mathrm{ab}}$ & $91.1 \pm 2.47^{\mathrm{ab}}$ \\
\hline BS2 $20 \mathrm{t} \mathrm{ha}^{-1}$ & $7.63 \pm 0.12^{b}$ & $2.80 \pm 0.45^{a}$ & $41.9 \pm 7.10^{b}$ & $44.6 \pm 7.98^{b}$ & $92.9 \pm 2.15^{b}$ \\
\hline Co-F & $7.51 \pm 0.20^{\mathrm{a}}$ & $3.35 \pm 0.44^{\mathrm{a}}$ & $46.5 \pm 8.75^{b c}$ & $49.8 \pm 9.90^{b c}$ & $92.1 \pm 3.79^{a}$ \\
\hline BS1 $10 \mathrm{tha}^{-1}+\mathrm{F}$ & $7.59 \pm 0.22^{a}$ & $3.00 \pm 1.34^{\mathrm{a}}$ & $29.6 \pm 5.61^{a b}$ & $32.5 \pm 1.00^{\mathrm{ab}}$ & $91.0 \pm 2.46^{a}$ \\
\hline BS1 $20 \mathrm{tha}^{-1}+\mathrm{F}$ & $7.58 \pm 0.12^{a}$ & $3.64 \pm 1.75^{\mathrm{a}}$ & $57.4 \pm 5.33^{c}$ & $61.0 \pm 6.13^{c}$ & $93.9 \pm 2.84^{\mathrm{a}}$ \\
\hline BS2 $10 \mathrm{tha}^{-1}+\mathrm{F}$ & $7.45 \pm 0.26^{a}$ & $3.38 \pm 2.00^{a}$ & $25.6 \pm 5.45^{\mathrm{a}}$ & $29.0 \pm 5.34^{\mathrm{a}}$ & $87.3 \pm 3.39^{a}$ \\
\hline BS2 $20 \mathrm{tha}^{-1}+\mathrm{F}$ & $7.63 \pm 0.10^{a}$ & $3.19 \pm 1.22^{\mathrm{a}}$ & $34.8 \pm 1.09^{a b}$ & $38.0 \pm 2.31^{\mathrm{ab}}$ & $91.7 \pm 2.72^{a}$ \\
\hline \multicolumn{6}{|c|}{ Loamy soil } \\
\hline Co & $7.83 \pm 0.21^{a}$ & $3.14 \pm 1.48^{\mathrm{a}}$ & $492.6 \pm 1.48^{a}$ & $495.8 \pm 2.98^{a}$ & $99.4 \pm 0.30^{a}$ \\
\hline BS1 $10 \mathrm{t} \mathrm{ha}^{-1}$ & $8.03 \pm 0.14^{a}$ & $3.01 \pm 1.50^{\mathrm{a}}$ & $490.8 \pm 2.47^{\mathrm{a}}$ & $493.9 \pm 2.69^{a}$ & $99.4 \pm 0.30^{\mathrm{a}}$ \\
\hline BS1 $20 \mathrm{t} \mathrm{ha}^{-1}$ & $8.00 \pm 0.13^{a}$ & $2.55 \pm 1.25^{\mathrm{a}}$ & $491.3 \pm 2.82^{a}$ & $493.8 \pm 2.67^{\mathrm{a}}$ & $99.5 \pm 0.25^{a}$ \\
\hline BS2 $10 \mathrm{t} \mathrm{ha}^{-1}$ & $7.97 \pm 0.16^{\mathrm{a}}$ & $2.60 \pm 1.23^{\mathrm{a}}$ & $491.8 \pm 4.37^{\mathrm{a}}$ & $494.4 \pm 2.46^{\mathrm{a}}$ & $99.5 \pm 0.25^{a}$ \\
\hline BS2 $20 \mathrm{t} \mathrm{ha}^{-1}$ & $7.91 \pm 0.15^{\mathrm{a}}$ & $2.88 \pm 1.16^{\mathrm{a}}$ & $492.2 \pm 3.82^{\mathrm{a}}$ & $495.4 \pm 3.23^{a}$ & $99.4 \pm 0.23^{a}$ \\
\hline $\mathrm{Co}-\mathrm{F}$ & $7.99 \pm 0.14^{\mathrm{a}}$ & $2.58 \pm 0.92^{a}$ & $492.4 \pm 2.94^{a}$ & $495.0 \pm 2.07^{\mathrm{a}}$ & $99.5 \pm 0.19^{a}$ \\
\hline BS1 $10 \mathrm{tha}^{-1}+\mathrm{F}$ & $7.91 \pm 0.16^{\mathrm{a}}$ & $2.78 \pm 1.42^{\mathrm{a}}$ & $492.7 \pm 2.57^{\mathrm{a}}$ & $495.5 \pm 2.64^{\mathrm{a}}$ & $99.4 \pm 0.30^{\mathrm{a}}$ \\
\hline BS1 $20 \mathrm{tha}^{-1}+\mathrm{F}$ & $7.98 \pm 0.12^{a}$ & $2.91 \pm 1.38^{a}$ & $492.7 \pm 2.34^{\mathrm{a}}$ & $495.6 \pm 2.36^{a}$ & $99.5 \pm 0.29^{a}$ \\
\hline BS2 $10 \mathrm{tha}^{-1}+\mathrm{F}$ & $8.00 \pm 0.17^{a}$ & $2.60 \pm 1.18^{a}$ & $493.4 \pm 2.18^{a}$ & $496.0 \pm 2.05^{\mathrm{a}}$ & $99.5 \pm 0.24^{a}$ \\
\hline BS2 $20 \mathrm{tha}^{-1}+\mathrm{F}$ & $7.98 \pm 0.16^{a}$ & $2.85 \pm 1.17^{\mathrm{a}}$ & $492.4 \pm 2.61^{a}$ & $495.3 \pm 2.49^{a}$ & $99.4 \pm 0.24^{a}$ \\
\hline
\end{tabular}

Ha-Hydrolytic acidity; SBC-Sum of basic cations; CEC-Cation exchange capacity; Bs-Base saturation Different letters between the individual treatments stand for a significant difference according to the LSD test $(p<0.05)$.

The average values of hydrolytic acidity (Ha) did not significantly change in any of the studied soils for the period of 3 years after the application of BS (Table 3 ). Regarding the sum of basic cations (SBC), in sandy soil, its values increased on average by $+26,+73$, +46 , and $+112 \%$ in treatments BS1 $10 \mathrm{tha}^{-1}$, BS1 $20 \mathrm{t} \mathrm{ha}^{-1}, \mathrm{BS} 210 \mathrm{tha}^{-1}$, and BS2 $20 \mathrm{t} \mathrm{ha}^{-1}$, respectively (Table 3 ). The effect was more pronounced at the higher application rate of BS. SBC increase after BS incorporation into the soil could be due to providing basic cations that were formed in BS during the process of production (pyrolysis) [31]. Conversely, SBC decreased (except for treatment BS1 $20 \mathrm{t} \mathrm{ha}^{-1}+\mathrm{F}$ ) by $-36,-45$, and $-25 \%$ in treatments BS1 $10 \mathrm{tha}^{-1}+\mathrm{F}$, BS2 $10 \mathrm{tha}^{-1}+\mathrm{F}$, and BS2 $20 \mathrm{tha}^{-1}+\mathrm{F}$, respectively after application of BS together with additional fertilization compared to fertilized control. However, the significant changes of SBS were observed only in treatment BS2 $10 \mathrm{tha}^{-1}+\mathrm{F}$. In loamy soil, the application of BS did not have any effect on SBC.

CEC reflected the trend in the values of Ha and SBC, i.e., an increase in CEC after BS application compared to unfertilized control (with stronger effect at BS2 and higher application rate of both BS), but also a decrease in average values of CEC in BS combined with additional fertilization (except for treatment BS1 $20 \mathrm{t} \mathrm{ha}^{-1}+\mathrm{F}$ ) compared to the fertilized control. Significant differences were observed only in sandy soil for treatment BS2 $20 \mathrm{t} \mathrm{ha}^{-1}(+93 \%)$ and BS2 $10 \mathrm{t} \mathrm{ha}^{-1}+\mathrm{F}(-42 \%)$ compared to their control treatments Co and Co-F, respectively (Table 3). In loamy soil, the differences between unfertilized and fertilized treatments were not significant. This can be explained as follows: in sandy soil, there are more favorable conditions for the oxidation of biochar, which contains carboxyl groups on its surface [32]. Carboxyl groups can also have a significant neutralizing effect [33], which resulted in a decrease in Ha, but also an increase in SBC and CEC. 
Application of BS significantly increased base saturation (Bs) by +13 and $+14 \%$ only in sandy soil in treatments with an application rate of $20 \mathrm{t} \mathrm{ha}^{-1}$ of both biochar substrates (BS1 $20 \mathrm{t} \mathrm{ha}^{-1}$ and BS2 $20 \mathrm{t} \mathrm{ha}^{-1}$, respectively) without fertilization. The application of BS with additional fertilization in sandy soil, nor any application of BS in loamy soil did not have a significant effect on changes in Bs, probably as a result of saturation of sorption complex with basic cations in both soils (in loamy soil, the sorption complex was even fully saturated $>95 \%$ ).

The content of total $\mathrm{P}$ in the soil generally depends on its content in the parent material and the soil organic matter [3], but also on its content in the fertilizer/additives applied to the soil. The content of $\mathrm{P}$ in biochar mainly depends on the P content in the feedstock and the conditions of biochar production [10]. The biochar substrates BS1 and BS2 contained $0.49 \%$ and $0.79 \%$ of phosphorus, respectively. It was expected that BS incorporation will have a positive effect on the overall increase in P content in both soils. In sandy soil, the content of total $\mathrm{P}$ increased by $+12,+35,+2$, and $+16 \%$ in treatments BS1 $10 \mathrm{tha}^{-1}$, BS1 $20 \mathrm{tha}^{-1}$, BS2 $10 \mathrm{t} \mathrm{ha}^{-1}$, and BS2 $20 \mathrm{t} \mathrm{ha}^{-1}$, respectively, compared to the unfertilized control (Table 4).

Table 4. Contents of total and available macro-nutrients (mean \pm standard deviation for 2018-2020).

\begin{tabular}{|c|c|c|c|c|c|c|c|c|}
\hline \multirow{2}{*}{ Treatment } & \multicolumn{4}{|c|}{ Total Content $\left(\mathrm{g} \mathrm{kg}^{-1}\right)$} & \multicolumn{4}{|c|}{ Available Content (mg kg-1) } \\
\hline & $\mathbf{P}$ & $\mathbf{K}$ & $\mathrm{Ca}$ & Mg & $\mathbf{P}$ & $\mathbf{K}$ & $\mathrm{Ca}$ & $\mathrm{Mg}$ \\
\hline \multicolumn{9}{|c|}{ Sandy soil } \\
\hline Co & $1.15 \pm 0.15^{\mathrm{a}}$ & $11.2 \pm 0.34^{\mathrm{a}}$ & $40.2 \pm 1.33^{\mathrm{a}}$ & $9.52 \pm 0.99^{a}$ & $374 \pm 65^{\mathrm{a}}$ & $166 \pm 78^{a}$ & $7362 \pm 1376^{a}$ & $255 \pm 28^{a}$ \\
\hline BS1 $10 \mathrm{t} \mathrm{ha}^{-1}$ & $1.29 \pm 0.11^{\mathrm{a}}$ & $11.5 \pm 0.28^{\mathrm{a}}$ & $40.9 \pm 0.99^{a}$ & $9.85 \pm 1.12^{\mathrm{a}}$ & $359 \pm 39^{a}$ & $226 \pm 35^{a}$ & $6758 \pm 2987^{a}$ & $231 \pm 41^{\mathrm{a}}$ \\
\hline BS1 $20 \mathrm{tha}^{-1}$ & $1.55 \pm 0.08^{c}$ & $12.4 \pm 0.36^{\mathrm{a}}$ & $33.5 \pm 6.89^{a}$ & $8.82 \pm 2.53^{a}$ & $370 \pm 26^{a}$ & $239 \pm 22^{a}$ & $5842 \pm 2907^{a}$ & $285 \pm 36^{a}$ \\
\hline BS2 $10 \mathrm{t} \mathrm{ha}^{-1}$ & $1.17 \pm 0.07^{\mathrm{a}}$ & $11.3 \pm 0.41^{\mathrm{a}}$ & $34.4 \pm 5.99^{a}$ & $7.99 \pm 1.99^{a}$ & $336 \pm 59^{a}$ & $174 \pm 41^{\mathrm{a}}$ & $5803 \pm 2699^{a}$ & $250 \pm 26^{a}$ \\
\hline BS2 $20 \mathrm{tha}^{-1}$ & $1.34 \pm 0.11^{\mathrm{b}}$ & $11.8 \pm 0.09^{a}$ & $31.1 \pm 10.3^{\mathrm{a}}$ & $7.36 \pm 2.37^{a}$ & $396 \pm 19^{a}$ & $215 \pm 59^{a}$ & $5371 \pm 2639^{a}$ & $275 \pm 39^{a}$ \\
\hline $\mathrm{Co}-\mathrm{F}$ & $1.06 \pm 0.05^{\mathrm{a}}$ & $11.5 \pm 0.23^{a}$ & $29.8 \pm 9.87^{\mathrm{a}}$ & $7.23 \pm 3.07^{a}$ & $329 \pm 44^{\mathrm{a}}$ & $200 \pm 28^{a}$ & $5773 \pm 1563^{a}$ & $280 \pm 55^{a}$ \\
\hline BS1 $10 \mathrm{tha}^{-1}+\mathrm{F}$ & $1.12 \pm 0.03^{\mathrm{ab}}$ & $11.2 \pm 0.35^{\mathrm{a}}$ & $39.4 \pm 5.89^{a}$ & $9.50 \pm 2.87^{a}$ & $290 \pm 39^{a}$ & $197 \pm 37^{\mathrm{a}}$ & $5927 \pm 1302^{\mathrm{a}}$ & $294 \pm 37^{\mathrm{a}}$ \\
\hline BS1 $20 \mathrm{tha}^{-1}+\mathrm{F}$ & $1.25 \pm 0.11^{\mathrm{b}}$ & $11.6 \pm 0.42^{\mathrm{a}}$ & $32.0 \pm 11.4^{\mathrm{a}}$ & $7.92 \pm 2.99^{a}$ & $362 \pm 48^{\mathrm{a}}$ & $213 \pm 35^{a}$ & $8854 \pm 2744^{b}$ & $281 \pm 22^{a}$ \\
\hline BS2 $10 \mathrm{tha}^{-1}+\mathrm{F}$ & $1.09 \pm 0.04^{\mathrm{a}}$ & $11.7 \pm 0.28^{\mathrm{a}}$ & $32.9 \pm 8.34^{\mathrm{a}}$ & $8.50 \pm 1.89^{a}$ & $321 \pm 62^{a}$ & $228 \pm 21^{a}$ & $7333 \pm 974^{a b}$ & $310 \pm 49^{a}$ \\
\hline BS2 $20 \mathrm{tha}^{-1}+\mathrm{F}$ & $1.16 \pm 0.06^{\mathrm{ab}}$ & $11.7 \pm 0.36^{\mathrm{a}}$ & $36.9 \pm 3.29^{a}$ & $9.11 \pm 2.75^{a}$ & $297 \pm 28^{a}$ & $263 \pm 18^{b}$ & $8675 \pm 1693^{b}$ & $301 \pm 38^{a}$ \\
\hline \multicolumn{9}{|c|}{ Loamy soil } \\
\hline Co & $1.01 \pm 0.08^{\mathrm{a}}$ & $14.1 \pm 0.44^{\mathrm{a}}$ & $42.3 \pm 5.67^{\mathrm{a}}$ & $14.9 \pm 1.21^{\mathrm{a}}$ & $166 \pm 48^{a}$ & $215 \pm 36^{a}$ & $9156 \pm 896^{a b}$ & $371 \pm 11^{a}$ \\
\hline BS1 $10 \mathrm{t} \mathrm{ha}^{-1}$ & $1.11 \pm 0.09^{a b}$ & $14.6 \pm 0.24^{\mathrm{a}}$ & $47.9 \pm 4.79^{\mathrm{a}}$ & $16.5 \pm 0.33^{b}$ & $126 \pm 59^{a}$ & $199 \pm 28^{a}$ & $9834 \pm 751^{b}$ & $366 \pm 19^{a}$ \\
\hline BS1 $20 \mathrm{t} \mathrm{ha}^{-1}$ & $1.16 \pm 0.10^{\mathrm{ab}}$ & $14.6 \pm 0.31^{\mathrm{a}}$ & $49.7 \pm 3.99^{a}$ & $19.6 \pm 1.11^{c}$ & $147 \pm 36^{\mathrm{a}}$ & $227 \pm 39^{a}$ & $8967 \pm 879^{a b}$ & $386 \pm 20^{a}$ \\
\hline BS2 $10 \mathrm{t} \mathrm{ha}^{-1}$ & $1.20 \pm 0.11^{\mathrm{ab}}$ & $14.5 \pm 0.15^{\mathrm{a}}$ & $45.0 \pm 4.56^{\mathrm{a}}$ & $16.0 \pm 0.46^{\mathrm{ab}}$ & $159 \pm 29^{a}$ & $207 \pm 26^{a}$ & $8618 \pm 235^{a}$ & $393 \pm 26^{a}$ \\
\hline BS2 $20 \mathrm{tha}^{-1}$ & $1.54 \pm 0.21^{b}$ & $14.5 \pm 0.09^{\mathrm{a}}$ & $45.6 \pm 3.87^{\mathrm{a}}$ & $16.4 \pm 0.49^{b}$ & $149 \pm 37^{a}$ & $208 \pm 37^{a}$ & $8334 \pm 649^{a}$ & $380 \pm 17^{a}$ \\
\hline Co-F & $1.07 \pm 0.04^{\mathrm{a}}$ & $14.9 \pm 0.12^{\mathrm{a}}$ & $45.8 \pm 1.23^{a}$ & $17.3 \pm 0.12^{\mathrm{a}}$ & $141 \pm 33^{a}$ & $191 \pm 68^{a}$ & $9875 \pm 976^{a}$ & $386 \pm 05^{a}$ \\
\hline BS1 $10 \mathrm{tha}^{-1}+\mathrm{F}$ & $1.09 \pm 0.04^{\mathrm{a}}$ & $14.8 \pm 0.22^{\mathrm{a}}$ & $43.5 \pm 4.35^{\mathrm{a}}$ & $17.0 \pm 0.45^{\mathrm{a}}$ & $166 \pm 28^{a}$ & $289 \pm 73^{a}$ & $8125 \pm 959^{a}$ & $389 \pm 03^{a b}$ \\
\hline BS1 $20 \mathrm{tha}^{-1}+\mathrm{F}$ & $1.22 \pm 0.10^{b}$ & $15.2 \pm 0.37^{\mathrm{a}}$ & $46.2 \pm 2.89^{a}$ & $17.9 \pm 1.13^{\mathrm{a}}$ & $157 \pm 19^{a}$ & $189 \pm 77^{a}$ & $9429 \pm 893^{a}$ & $435 \pm 20^{b}$ \\
\hline BS2 $10 \mathrm{tha}^{-1}+\mathrm{F}$ & $1.15 \pm 0.12^{\mathrm{ab}}$ & $14.6 \pm 0.18^{a}$ & $43.5 \pm 4.21^{\mathrm{a}}$ & $17.1 \pm 0.99^{a}$ & $156 \pm 29^{a}$ & $223 \pm 71^{a}$ & $9689 \pm 789^{a}$ & $396 \pm 17^{\mathrm{ab}}$ \\
\hline BS2 $20 \mathrm{tha}^{-1}+\mathrm{F}$ & $1.16 \pm 0.11^{a b}$ & $14.4 \pm 0.35^{\mathrm{a}}$ & $42.9 \pm 3.51^{\mathrm{a}}$ & $16.6 \pm 2.31^{a}$ & $145 \pm 34^{\mathrm{a}}$ & $177 \pm 79^{a}$ & $8398 \pm 941^{a}$ & $404 \pm 38^{a b}$ \\
\hline
\end{tabular}

Different letters between the individual treatments stand for a significant difference according to the LSD test $(p<0.05)$.

A significant effect was observed only in treatments with the higher application rates of both BS over a period of 3 years (BS1 $20 \mathrm{t} \mathrm{ha}^{-1}$ and BS2 $20 \mathrm{tha}^{-1}$ ). In fertilized treatments, the content of total P increased by $+6,+18,+3$ and $+10 \%$ in treatments BS1 $10 \mathrm{tha}^{-1}+\mathrm{F}$, BS1 $20 \mathrm{tha}^{-1}+\mathrm{F}$, BS2 $10 \mathrm{tha}^{-1}+\mathrm{F}$ and BS2 $20 \mathrm{tha}^{-1}+\mathrm{F}$, respectively, compared to the fertilized control Co-F. However, a significant effect was found only at the treatment BS1 $20 \mathrm{t} \mathrm{ha}^{-1}+\mathrm{F}$. The content of total P in loamy soil increased significantly only in treatments BS2 $20 \mathrm{t} \mathrm{ha}^{-1}$ and BS1 $20 \mathrm{tha}^{-1}+\mathrm{F}$ by +53 and $+14 \%$ compared to their control treatments. A higher content of total $\mathrm{P}$ in the soil should also result in a higher content of available $\mathrm{P}$, however, this was only partially confirmed in our study. The content of total P positively correlated with the content of available P ( $\mathrm{r}=0.743, p<0.001)$ but only in sandy soil. The content of available $\mathrm{P}$ in both control treatments on sandy soil was above $200 \mathrm{mg}$ $\mathrm{kg}^{-1}$ which corresponds with a very high content according to criteria for evaluating the 
contents of available P in arable soil-Mehlich III. [3,22]. In such cases, fertilization with this nutrient is omitted. In our experiment, the values of available P fluctuated in the range from 336 to $396 \mathrm{mg} \mathrm{kg}^{-1}$ and in the range of $290-362 \mathrm{mg} \mathrm{kg}^{-1}$ in treatments with applied BS without fertilization and with fertilization, respectively (Table 4), but the differences were not significant. No effect on an increase of available P content after application of BS to the soil may be related to the adjustment/enrichment of the resulting biochar/product with phosphorus as was reported by Hossian, et al. [10]. The other reasons might be an uptake of available $\mathrm{P}$ by crops, but also the behavior of $\mathrm{P}$ in slightly alkaline soil. The accumulation of $\mathrm{P}$ in soil depends on the clay content and mineralogical composition, organic matter content, and soil $\mathrm{pH}$ [34]. In our study, the content of total P increased in investigated soils, but the content of available P did not significantly change. Biochar substrates contained $\mathrm{P}$, they had an alkaline $\mathrm{pH}$ and were additionally applied to slightly alkaline soils. This can be the reason for total $\mathrm{P}$ accumulation and a decrease in available P because of chemisorption [35]. Biochar can absorb cations such as $\mathrm{Al}^{3+}, \mathrm{Fe}^{3+}$, and $\mathrm{Ca}^{2+}$, which can lead to delayed $\mathrm{P}$ absorption or precipitation. Organic molecules could sorb onto biochar reducing its capacity to form chelates [36]. Xu, et al. [35] reported a P sorption increase in acidic soil but a decrease in alkaline soil. The authors attributed an increase in $\mathrm{P}$ sorption after biochar addition to Ca-induced P sorption/precipitation. In other studies, the P sorption findings are inconsistent. Soinne, et al. [37] reported that P sorption did not differ in sandy and clay soils after biochar treatments. Conversely, the study of Nelson, et al. [38] indicated a reduction of P leaching after biochar application. Ngatia, et al. [39] reported the biochar properties resulting from biochar production conditions (such as pyrolysis temperature, feedstock, etc.) as the main reason for P sorption and P availability for crops after biochar application. In addition, an increase of pyrolysis temperature (in the biochar production process) results in a loss of $\mathrm{O}-$ alkyl carbon and an accumulation of aromatic carbon [40] that favors P sorption [39]. In our case, available P was also affected by soil sorption in different ways depending on the soil type/class, type of BS, or their combination with additional fertilization. In sandy soil and in the BS2 + F treatment, linear dependence was found between CEC and available P. An increase in CEC of $1 \mathrm{mmol} \mathrm{kg}^{-1}$ resulted in an increase in $\mathrm{P}$ availability by $4.03 \mathrm{mg} \mathrm{kg}^{-1}$ of soil over a period of 3 years in this treatment (Figure 1A). The SBC also correlated with available P. In sandy soil in treatments BS1 (Figure 1B) and BS2 + F (Figure 1C), the availability of P increased by 2.08 and $3.95 \mathrm{mg} \mathrm{kg}^{-1}$, respectively due to an increase of SBC by $1 \mathrm{mmol} \mathrm{kg}^{-1}$ for the observed period. In loamy soil in treatments BS2 (Figure 1D) and BS1 + F (Figure 1E), the availability of P increased by 3.34 and $3.83 \mathrm{mg} \mathrm{kg}^{-1}$ for each $1 \mathrm{mmol} \mathrm{kg}^{-1}$ of SBC, respectively.

The initial contents of total and available $\mathrm{K}$ in both soil types investigated in our study were not significantly different. The application of BS and their combination with additional fertilization increased the content of total $\mathrm{K}$ mostly insignificantly even though both substrates contained additional $\mathrm{K}$. In our study in sandy soil, the content of available $\mathrm{K}$ moved from good to high stock due to application of BS2 at a rate of $20 \mathrm{tha} \mathrm{h}^{-1}$ and BS1 $20 \mathrm{tha}^{-1}+\mathrm{F}$. In loamy soil, the content of available $\mathrm{K}$ was good in the unfertilized control and satisfactory in the fertilized control. The application of BS with additional fertilization slightly increased available K content, however not significantly. Major, et al. [41] reported that the content of available $\mathrm{K}$ increases after incorporation of alkaline biochar into acidic soil. However, in our study, the pH of both soils was slightly alkaline and increased slightly after BS incorporation (Table 3). Of the total content of $\mathrm{K}$ in the soil, about $4-5 \%$ is available for crops [3]. In our study, significant correlation between total and available $\mathrm{K}$ was found only in sandy soil $(\mathrm{r}=0.740, p \leq 0.001)$. Available $\mathrm{K}$ constituted $3.35,1.96,1.93,1.54$ and $1.82 \%$ of the total K content in treatments Co, BS1 $10 \mathrm{tha}^{-1}, \mathrm{BS}^{2} 20 \mathrm{t} \mathrm{ha}^{-1}$, BS2 $10 \mathrm{t} \mathrm{ha}^{-1}$ and BS2 $20 \mathrm{tha}^{-1}$, respectively. This observation may suggest that BS eliminated the availability of $\mathrm{K}$ of its total content. Biochar can contribute to improving nutrient retention capacity of soil due to its large surface area, porosity, and presence of both non-polar and polar surface sites $[42,43]$. Biochar reduces nutrient leaching and loss of nutrients through enhancing the ion exchange capacity [11]. When BS were applied in sandy soil together with additional 
fertilization, the contents of available $\mathrm{K}$ ranged from 1.74 to $2.25 \%$ of the total $\mathrm{K}$. In this case, the BS did not have any effect on availability of $\mathrm{K}$ of its total content. The same effect was observed in loamy soil, the availability of K ranged from 1.23 to $1.96 \%$ of total K. Available $\mathrm{K}$ was also affected by soil sorption in different ways depending on the soil type/class, the type of BS or their combination with additional fertilization. In sandy soil, in BS2 treatment, the availability of $\mathrm{K}$ increased by 2.54 and $2.52 \mathrm{mg} \mathrm{kg}^{-1}$ soil for each $1 \mathrm{mmol} \mathrm{kg}{ }^{-1} \mathrm{SBC}$ (Figure 2A) and CEC (Figure 2B), respectively.
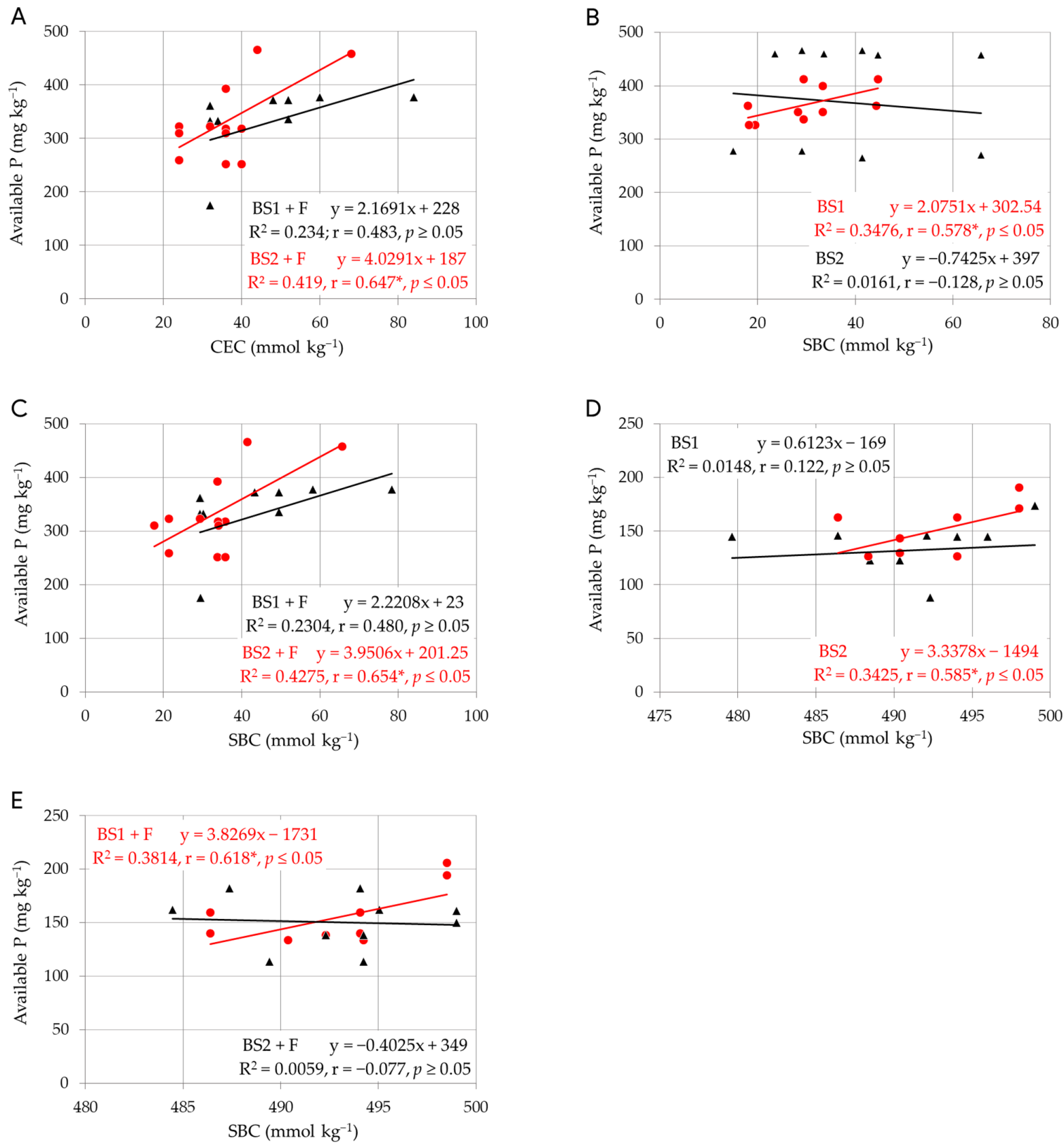

Figure 1. The linear dependence between selected soil properties and $\mathrm{P}$ availability for chosen treatments in sandy soil: (A) Cation exchange capacity (CEC) in fertilized treatments; (B) Sum of basic cations (SBC) in nonfertilized treatments; (C) Sum of basic cations (SBC) in fertilized treatments. The linear dependence between sum of basic cations (SBC) and P availability in loamy soil: (D) In chosen nonfertilized treatments; (E) In chosen fertilized treatments. Red circles and * indicate significant correlation at $p \leq 0.05$. 
A
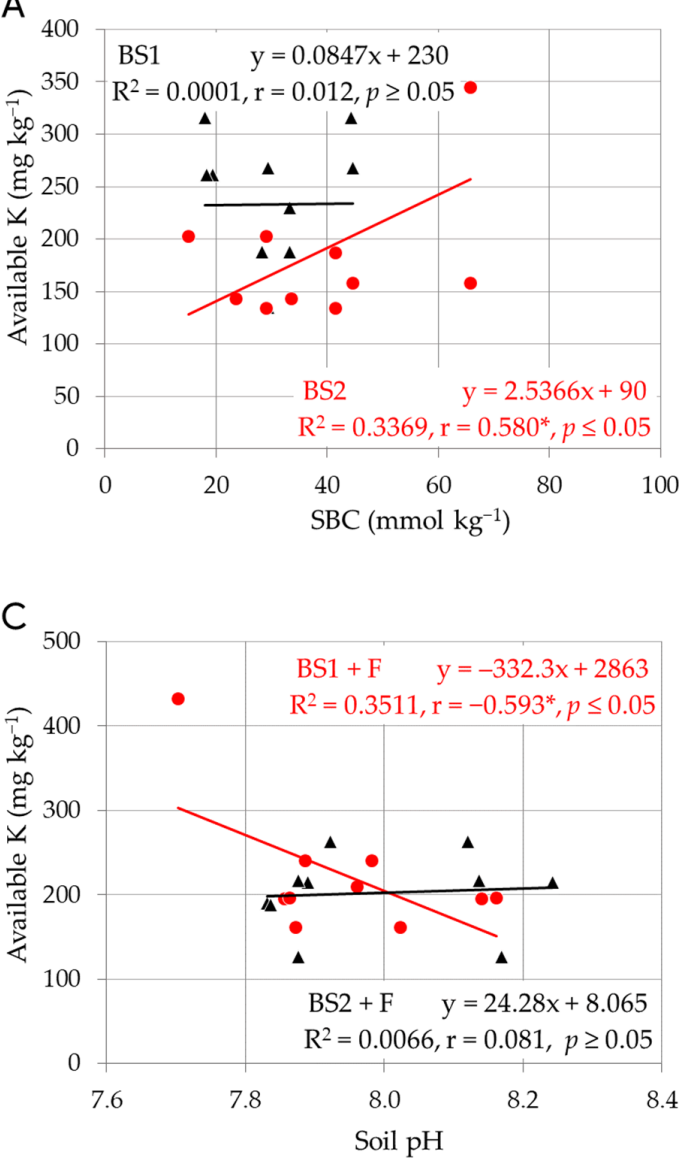

B

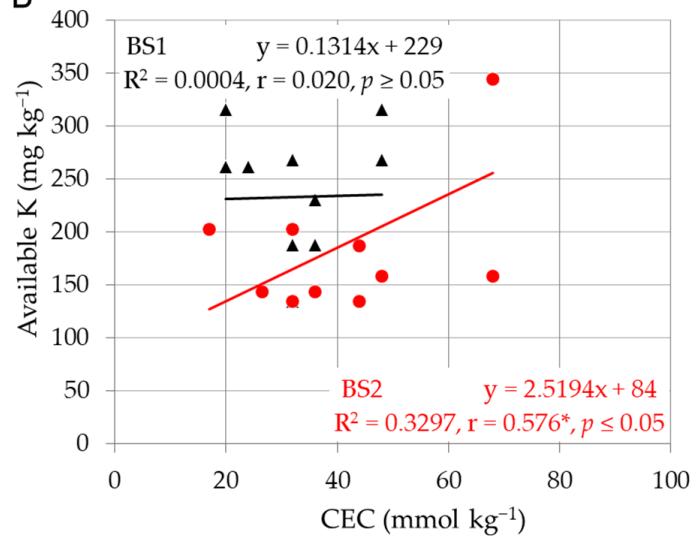

Figure 2. The linear dependence between selected soil properties and $\mathrm{K}$ availability for chosen treatments: (A) Sum of basic cations (SBC) in nonfertilized treatments in sandy soil; (B) Cation exchange capacity (CEC) in nonfertilized treatments in sandy soil; (C) Soil $\mathrm{pH}$ in fertilized treatments in loamy soil. Red circles and ${ }^{*}$ indicate significant correlation at $p \leq 0.05$.

In loamy soil, a significant negative linear dependence between $\mathrm{pH}$ and available $\mathrm{K}$ was observed only in the BS1 $+\mathrm{F}$ treatment (Figure 2C). In this treatment, increasing soil $\mathrm{pH}$ by $1 \mathrm{pH}$ unit could reduce the availability of $\mathrm{K}$ by $332 \mathrm{mg} \mathrm{kg}^{-1}$ over a period of 3 years.

Xiao, et al. [44] stated that biochar also contains basic cations, including $\mathrm{Ca}$ and $\mathrm{Mg}$. Therefore, it is assumed that after biochar incorporation into the soil, the $\mathrm{pH}$ will be neutralized, especially in acidic soils, but also that the content of $\mathrm{Ca}$ and $\mathrm{Mg}$ cations in the soil will increase. In our study, both tested BS contained total Ca and Mg (BS1: Ca $=42,000 \mathrm{mg} \mathrm{kg}^{-1}, \mathrm{Mg}=4500 \mathrm{mg} \mathrm{kg}^{-1}$; BS2: $\mathrm{Ca}=22,000 \mathrm{mg} \mathrm{kg}^{-1}, \mathrm{Mg}=5800 \mathrm{mg} \mathrm{kg}^{-1}$ ). In sandy soils, the total content of $\mathrm{Ca}$ and $\mathrm{Mg}$ fluctuated in a relatively wide range. The application of BS had no effect on total $\mathrm{Ca}$ and $\mathrm{Mg}$ content in the soil during the observed period (Table 4). An overall lower content of total $\mathrm{Ca}$ and $\mathrm{Mg}$ was determined at a higher application rate of both BS compared to the unfertilized control. Such a trend was not found in the case of the application of BS in combination with additional fertilization compared to the fertilized control. The contents of available $\mathrm{Ca}$ and $\mathrm{Mg}$ changed due to the application of BS compared to the unfertilized control, but due to the large variability of data, no statistical significance was observed. A significant increase in available Ca by +53 and $+50 \%$ was found in treatments with higher rates of both substrates combined with additional fertilization (BS1 $20 \mathrm{tha}^{-1}+\mathrm{F}$ and BS2 $20 \mathrm{t} \mathrm{ha}^{-1}+\mathrm{F}$, respectively) compared to the fertilized control Co-F. Hussain, et al. [40] reported that biochar increases the availability of $\mathrm{Ca}$ and $\mathrm{Mg}$ in soils, but more pronounced effects shall be observed at lower rather than higher rates, which does not fully correspond to the results of our study (Table 4). In loamy soil, the application of BS did not have effect on content of total and available Ca (Table 4). 
In loamy soil, the content of total $\mathrm{Mg}$ significantly increased by $+11,+32$ and $+10 \%$ in unfertilized treatments BS1 $10 \mathrm{t} \mathrm{ha}^{-1}$, BS1 $20 \mathrm{t} \mathrm{ha}^{-1}$ and BS2 $20 \mathrm{t} \mathrm{ha}^{-1}$, respectively compared to control treatment $\mathrm{Co}$. However, the content of available $\mathrm{Mg}$ was not affected. Although the application of BS with additional fertilization did not significantly change the content of total $\mathrm{Mg}$, a significant increase (by $+13 \%$ ) of the content of available $\mathrm{Mg}$ was observed in the treatment BS1 $10 \mathrm{t} \mathrm{ha}^{-1}+\mathrm{F}$ compared to control Co-F. Overall, it should be emphasized that the content of available $\mathrm{Mg}$ in all treatments on loamy soil was very high according to the criteria for evaluating available $\mathrm{Mg}$ for arable soil [3] and $\mathrm{Mg}$ fertilization in such field conditions can be omitted. The application of biochar also enhances nutrient retention by increasing the soil $\mathrm{pH}$ [45]. After application of BS, $\mathrm{pH}$ in both soils increased or remained slightly alkaline, this affected the availability of $\mathrm{Ca}$ and $\mathrm{Mg}$ in different ways. In sandy soil, linear relationship was determined between available $\mathrm{Ca}$ and soil $\mathrm{pH}$ but only in the BS2 treatments (Figure 3A). On the other hand, with increasing SBC and CEC, available Ca content decreased but only in BS2 + F treatments (Figure 3B,C). In sandy soil, the availability of $\mathrm{Mg}$ in BS2 increased with the improvement of sorption (i.e., the increase of SBC, CEC and Bs), but no linear relationships were found in other treatments. In loamy soil, higher soil $\mathrm{pH}$ decreased $\mathrm{Mg}$ availability (Figure 3D) and higher SBC increased $\mathrm{Mg}$ availability but only in BS1 + F treatments (Figure 3E). These findings indicate that the relationships between soil $\mathrm{pH}$, sorption and $\mathrm{Ca}$ and $\mathrm{Mg}$ availability are different and depend on the soil texture, the type of BS and BS combination with additional fertilization.
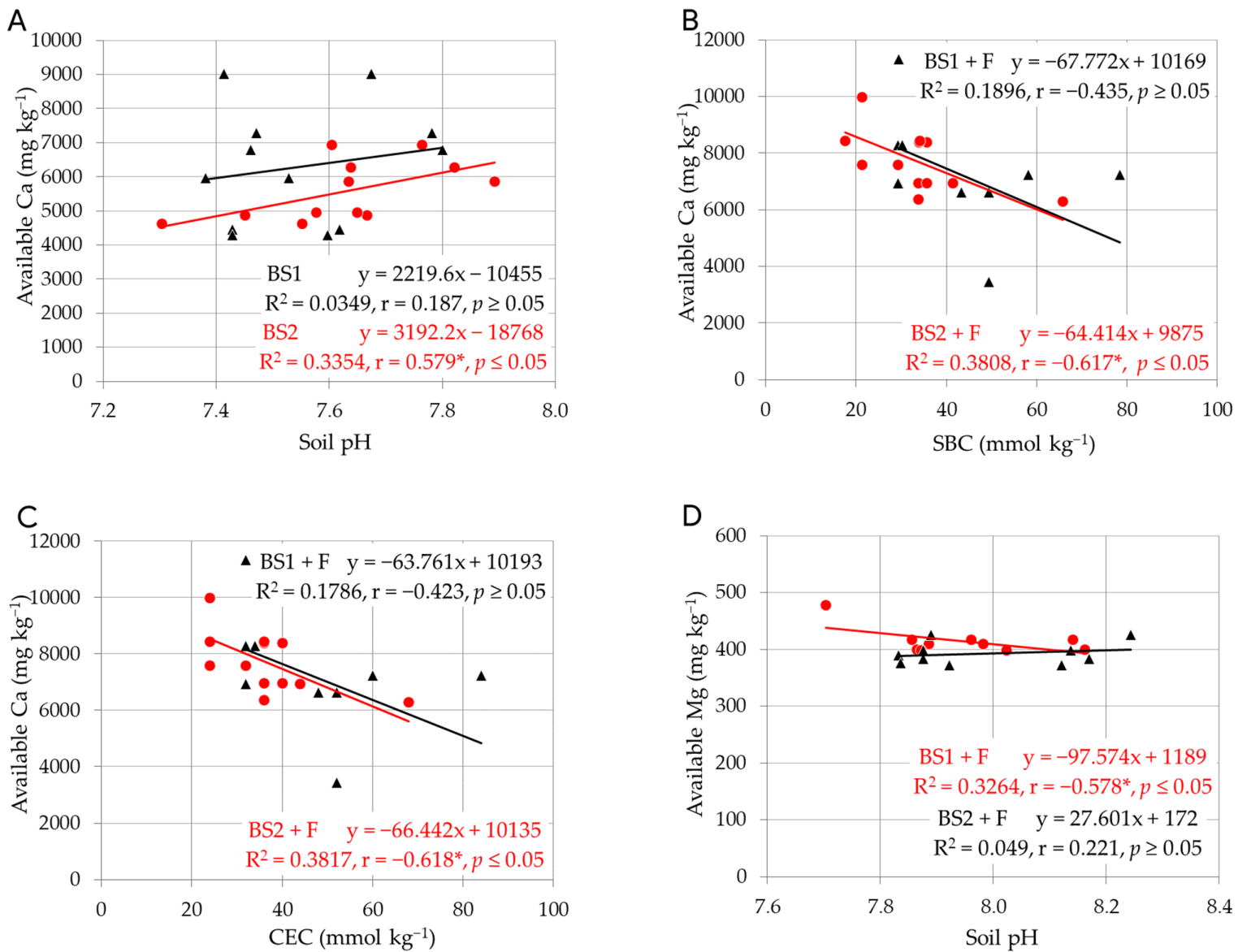

Figure 3. Cont. 


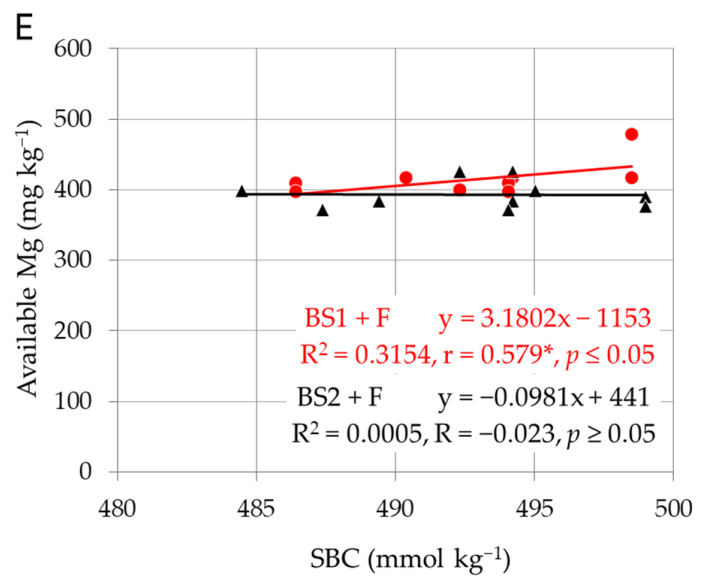

Figure 3. The linear dependence between selected soil properties and Ca availability for chosen treatments in sandy soil: (A) Soil pH in nonfertilized treatments; (B) Sum of basic cations (SBC) in fertilized treatments; (C) Cation exchange capacity (CEC) in fertilized treatments. The linear dependence between selected soil properties and $\mathrm{Mg}$ availability for chosen treatments in loamy soil: (D) Soil pH in fertilized treatments; (E) Sum of basic cations (SBC) in fertilized treatments. Red circles and * indicate correlation at $p \leq 0.05$.

\section{Conclusions}

According to the results of this study, the application of biochar substrates (BS) had a bigger effect on soil $\mathrm{pH}$ and sorption parameters in sandy soil when compared to the effect observed in loamy soil. An application dose of $20 \mathrm{t} \mathrm{ha}^{-1}$ of both types of BS alone showed the most favorable effects on the sum of basic cations, cation exchange capacity, and base saturation. This study also showed that BS and their combination with additional fertilization increased the total content of $\mathrm{P}$ in both soils. At the same time, BS combined with fertilization significantly increased the content of available $\mathrm{Ca}$ in sandy soil and available Mg in loamy soil. BS could be utilized at least partially as a suitable substitute to insufficient inputs of some nutrients, especially phosphorus. However, it is extremely important to address $\mathrm{P}$ accessibility, especially on alkaline soils, which is a challenge for further research activities in this area. Therefore, in addition to the total supply of nutrients, their availability to plants must be addressed in the future.

Based on the findings of this study, the application of BS demonstrated an improved soil nutrient regime which could assist healthy and sufficient crop production and sustainable soil management in common practice especially in sandy soils and overall, in soils with low fertility in the framework of Central Europe.

Author Contributions: Conceptualization, V.Š.; methodology, V.Š.; investigation, J.H., V.Š. and E.A.; resources, J.H.; data curation, V.Š. and E.A.; writing—original draft preparation, V.Š.; writingreview and editing, V.Š., E.A. and J.H., visualization, V.Š. and E.A.; supervision, V.Š. and J.H.; funding acquisition, J.H and E.A. All authors have read and agreed to the published version of the manuscript.

Funding: This publication was supported by the Operational program Integrated Infrastructure within the project: Sustainable smart farming systems taking into account the future challenges 313011W112, co-financed by the European Regional Development Fund.

Institutional Review Board Statement: Not applicable.

Conflicts of Interest: The authors declare no conflict of interest. The funders had no role in the design of the study; in the collection, analyses, or interpretation of data; in the writing of the manuscript, or in the decision to publish the results. 


\section{References}

1. Kobza, J. Aktuálny stav a vývoj obsahu prístupného draslíka v pol'nohospodárskych pôdach Slovenska [Current state and development of available potassium in agricultural soils of Slovakia]. Agrochemistry 2019, 2, 12-17. Available online: http: / /agrochemia.uniag.sk/pdf/agrochemia_2_kobza_3.pdf (accessed on 19 March 2021). (In Slovak).

2. Ložek, O.; Slamka, P.; Gáborík, Š.; Vicianová, M.; Kobza, J. Dynamika zmien obsahu prístupného fosforu v pôdach na Slovensku [The dynamics of changes of available phosphorus soil content in Slovakia]. Agrochemistry 2019, 1, 3-12. Available online: http://agrochemia.uniag.sk/pdf/agrochemia_1_2019_lozek_1.pdf (accessed on 20 March 2021). (In Slovak).

3. Kováčik, P.; Ryant, P. Agrochémia, Princípy A Prax [Agrochemistry, Principles and Practice]; SPU: Nitra, Slovakia, 2019; p. 358. (In Slovak)

4. Vaněk, V.; Ložek, O.; Balík, J.; Pavlíková, D.; Tlustoš, P. Výživa Pol’ných a Záhradných Plodín [Nutrition of Field and Garden Crops]; Profi Press: Praha, Czechia, 2013; p. 175. (In Slovak)

5. Šimanský, V.; Polláková, N.; Chlpík, J.; Kolenčík, M. Pôdoznalectvo [Soil Science]; SPU: Nitra, Slovakia, 2018; p. 398. (In Slovak)

6. Kováčik, P. Princípy a Spôsoby Výživy Rastlín. [Principles and Methods of Plant Nutrition]; SPU: Nitra, Slovakia, 2014; p. 278. (In Slovak)

7. Jeffery, S.; Abalos, D.; Spokas, K.A.; Verheijen, F.G.A. Biochar effects on crop yield. In Biochar for Environmental Management: Science, Technology and Implementation, 2nd ed.; Lehman, J., Joseph, S., Eds.; Routledge: London, UK, 2015; pp. $301-325$.

8. Ajema, L. Effects of biochar application on beneficial soil organism review. Int. J. Res. Stud. Sci. Eng. Technol. 2018, 5, 9-18.

9. Lehmann, J.; Gaunt, J.; Rondon, M. Bio-char sequestration in terrestrial ecosystems-A review. Mitig. Adapt. Strateg. Glob. Chang. 2006, 11, 403-427. [CrossRef]

10. Hossain, M.Z.; Bahar, M.M.; Sarkar, B.; Donne, S.W.; Ok, Y.S.; Palansooriya, K.N.; Kirkham, S.; Chowdhury, M.B.; Bolan, N. Biochar and its importance on nutrient dynamics in soil and plant. Biochar 2020, 2, 379-420. [CrossRef]

11. DeLuca, T.H.; Gundale, M.J.; MacKenzie, M.D.; Jones, D.L. Biochar effects on soil nutrient transformations. In Biochar for Environmental Management: Science, Technology and Implementation, 2nd ed.; Lehman, J., Joseph, S., Eds.; Routledge: London, UK, 2015; pp. 421-454.

12. Gwenzi, W.; Nyambishi, T.J.; Chaukura, N.; Mapope, N. Synthesis and nutrient release patterns of a biocharbased N-P-K slow-release fertilizer. Int. J. Environ. Sci. Technol. 2018, 15, 405-414. [CrossRef]

13. Šimanský, V.; Aydın, E.; Igaz, D.; Horák, J. Biochar application should be promoted for longer term environmental benefits instead of immediate economical profits: Case study on Haplic Luvisol in Slovakia. Agriculture 2020, 66, 171-176. [CrossRef]

14. Šimanský, V.; Horák, J.; Polláková, N.; Juriga, M.; Jonczak, J. Will the macro and micronutrient content in biochar show in the higher content of the individual parts of corn? J. Elem. 2019, 24, 525-537.

15. Spokas, K.A.; Reicosky, D.C. Impacts of sixteen different biochars on soil greenhouse gas production. Ann. Environ. Sci. 2009, 3, 179-193.

16. Liu, J.; Schulz, H.; Brandl, S.; Miehtke, H.; Huwe, B.; Glaser, B. Short-term effect of biochar and compost on soil fertility and water status of a Dystic Cambisol in NE Germany under field conditions. J. Plant Nutr. Soil Sci. 2012, 175, 698-707. [CrossRef]

17. Turky, M.M.; El-Sayed, M.M.; Awad, M.Y.; Abdel-Mawgoud, A.S.A. Use natural soil amendments in improving hydro-physical properties and wheat crop production of a new reclaimed area, Sohag governorate, Egypt. Arch. Agric. Sci. J. 2020, 3, 214-230. [CrossRef]

18. Prakongkep, N.; Gilkes, R.J.; Wisawapipat, W.; Leksungnoen, P.; Kerdchana, C.; Inboonchuay, T.; Delbos, E.; Strachan, L.J.; Ariyasakul, P.; Ketdan, C.; et al. Effects of biochar on properties of tropical sandy soils under organic agriculture. J. Agric. Sci. 2021, 13, 1. [CrossRef]

19. Šimanský, V.; Jonczak, J.; Parzych, A.; Horák, J. Contents and bioaccumulation of nutrients from soil to corn organs after application of different biochar doses. Carpathian J. Earth Environ. Sci. 2018, 13, 315-324. [CrossRef]

20. Laghari, M.; Mirjat, M.S.; Hu, Z.; Fazal, S.; Xiao, B.; Hu, M.; Chen, Z.; Guo, D. Effects of biochar application rate on sandy desert soil properties and sorghum growth. Catena 2015, 135, 313-320. [CrossRef]

21. El-Naggar, A.; Soo Lee, S.; Rinklebe, J.; Farooq, M.; Song, H.; Sarmah, A.K.; Zimmerman, A.R.; Ahmad, M.; Shaheen, S.M.; Sik Ok, Y. Biochar application to low fertility soils: A review of current status, and future prospects. Geoderma 2019, 337, 536-554. [CrossRef]

22. World Reference Base for Soil Resources 2014. In International Soil Classification System for Naming Soils and Creating Legends for Soil Maps. Update 2015; World Soil Resources Reports No. 106; FAO: Rome, Italy, 2015; Available online: http://www.fao.org/3/i379 4en/I3794en.pdf (accessed on 13 June 2021).

23. Šrank, D.; Šimanský, V. Physical properties of texturally different soils after application of biochar substrates. Agriculture. 2020, 66, 45-55. [CrossRef]

24. Hrivňáková, K.; Makovníková, J.; Barančíková, G.; Bezák, P.; Bezáková, Z.; Dodok, R.; Grečo, V.; Chlpík, J.; Kobza, J.; Lištjak, J.; et al. Jednotné Pracovné Postupy Rozborov Pôd. [Uniform Operation Procedures of Soil Analyses]; VÚPOP: Bratislava, Slovakia, 2011; p. 113. (In Slovak)

25. Mehlich, A. Mehlich 3 soil test extractant: A modification of Mehlich 2 extractant. Commun. Soil Sci. Plant Anal. 1984, 15, 1409-1416. [CrossRef]

26. Horák, J. Testing biochar as a possible way to ameliorate slightly acidic soil at the research field located in the Danubian lowland. Acta Hortic. Regiotect. 2015, 18, 20-24. [CrossRef] 
27. Teutscherova, N.; Vazquez, E.; Masaguer, A.; Navas, M.; Scow, K.M.; Schmidt, R.; Benito, M. Comparison of lime- and biocharmediated $\mathrm{pH}$ changes in nitrification and ammonia oxidizers in degraded acid soil. Biol. Fertil. Soils 2017, 53, 811-821. [CrossRef]

28. Mandal, S.; Donner, E.; Vasileiadis, S.; Skinner, W.; Smith, E.; Lombi, E. The effect of biochar feedstock, pyrolysis temperature, and application rate on the reduction of ammonia volatilisation from biochar-amended soil. Sci. Total Environ. 2018, 627, 942-950. [CrossRef]

29. Toková, L.; Igaz, D.; Horák, J.; Aydin, E. Effect of biochar application and re-application on soil bulk density, porosity, saturated hydraulic conductivity, water content and soil water availability in a silty loam Haplic Luvisol. Agronomy 2020, $10,1005$. [CrossRef]

30. Yuang, J.H.; $\mathrm{Xu}, \mathrm{R} . \mathrm{K}$. The forms of alkalis in the biochars produced from crop residues at different temperatures. Bioresour. Technol. 2011, 102, 3488-3497. [CrossRef] [PubMed]

31. Šimanský, V.; Horák, J.; Igaz, D.; Balashov, E.; Jonczak, J. Biochar and biochar with N fertilizer as a potential tool for improving soil sorption of nutrients. J. Soils Sediments 2018, 18, 1432-1440. [CrossRef]

32. Lehmann, J.; Stephen, J. Biochar effect on soil hydrology. In Biochar for Environmental Management: Science, Technology and Implementation, 2nd ed.; Lehman, J., Joseph, S., Eds.; Routledge: London, UK, 2015; pp. 543-563.

33. Novak, J.M.; Busscher, W.J.; Laird, D.L.; Ahmedna, M.; Watts, D.W.; Niandou, M.A.S. Impact of biochar amendment on fertility of a southeastern Coastal Plain soil. Soil Sci. 2009, 174, 105-112. [CrossRef]

34. Casson, J.P.; Bennett, D.R.; Nolan, S.C.; Olson, B.M.; Ontkean, G.R. Degree of phosphorus saturation thresholds in manureamended soils of Alberta. J. Environ. Qual. 2006, 35, 2212-2221. [CrossRef]

35. Xu, G.; Sun, J.; Shao, H.; Chang, S.X. Biochar had effects on phosphorus sorption and desorption in three soils with differing acidity. Ecol. Eng. 2014, 62, 54-60. [CrossRef]

36. Xu, C.Y.; Hosseini-Bai, S.; Hao, Y.; Rachaputi, R.; Wang, H.; Xu, Z.; Wallace, H. Effect of biochar amendment on yield and photosynthesis of peanut on two types of soils. Environ. Sci. Pollut. Res. 2015, 22, 6112-6125. [CrossRef]

37. Soinne, H.; Hovi, J.; Tammeorg, P.; Turtola, E. Effect of biochar on phosphorus sorption and clay soil aggregate stability. Geoderma 2014, 219-220, 162-167. [CrossRef]

38. Nelson, N.O.; Agudelo, S.C.; Yuan, W.Q.; Gan, J. Nitrogen and phosphorus availability in biochar-amended soils. Soil Sci. 2011, 176, 218-226. [CrossRef]

39. Ngatia, L.W.; Hsieh, Y.P.; Nemours, D.; Fu, R.; Taylor, R.W. Potential phosphorus eutrophication mitigation strategy: Biochar carbon composition, thermal stability and $\mathrm{pH}$ influence phosphorus sorption. Chemosphere 2017, 180, 201-211. [CrossRef]

40. Shackley, S.; Ruysschaert, G.; Zwart, K.; Glaser, B. Biochar in European Soils and Agriculture; Routledge: New York, NY, USA; London, UK, 2016; p. 301.

41. Major, J.; Rondon, M.; Molina, D.; Riha, S.J.; Lehmann, J. Maize yield and nutrition during 4 years after biochar application to a Colombian savanna oxisol. Plant Soil 2010, 333, 117-128. [CrossRef]

42. Hussain, M.; Farooq, M.; Nawaz, A.; Al-Sadi, A.M.; Solaiman, Z.M.; Alghamdi, S.S.; Ammara, U.; Sik Ok, Y.; Siddique, K.H.M. Biochar for crop production: Potential benefits and risks. J. Soils Sed. 2017, 17, 685-716. [CrossRef]

43. Yu, X.; Tian, X.; Lu, Y.; Liu, Z.; Guo, Y.; Chen, J.; Li, C.; Zhang, M.; Wan, Y. Combined effects of straw-derived biochar and bio-based polymer-coated urea on nitrogen use efficiency and cotton yield. Chem. Speciat. Bioavailab. 2018, 30, 112-122. [CrossRef]

44. Xiao, R.; Wang, J.J.; Gaston, L.A.; Zhou, B.; Park, J.; Li, R.; Dodla, S.K.; Zhang, Z. Biochar produced from mineral salt-impregnated chicken manure: Fertility properties and potential for carbon sequestration. Waste Manag. 2018, 78, 802-810. [CrossRef] [PubMed]

45. Mendez, A.; Gomez, A.; Paz-Ferreiro, J.; Gasco, G. Effects of sewage sludge biochar on plant metal availability after application to a Mediterranean soil. Chemosphere 2012, 89, 1354-1359. [CrossRef] 